\title{
PENGUATAN ORGANISASI DAN PROSES PENGURUSAN P-IRT KELOMPOK USAHA SALAK DESA GIRIKERTO SLEMAN DAERAH ISTIMEWA YOGYAKARTA
}

\author{
Insiwijati Prasetyaningsih ${ }^{1}$, Umi Murtini ${ }^{2}$, Bambang Purnomo Hediono ${ }^{3}$ \\ ${ }^{1}$ Fakultas Bisnis, Universitas Kristen Duta Wacana \\ Email: insiwijati@gmail.com \\ ${ }^{2}$ Fakultas Bisnis , Universitas Kristen Duta Wacana \\ Email: umimt@staff.ukdw.ac.id \\ ${ }^{3}$ Fakultas Bisnis, Universitas Kristen Duta Wacana \\ Email: bhediono@yahoo.com
}

\begin{abstract}
ABSTRAK
Kegiatan pendampingan telah berjalan selama lebih dari satu tahun, pada tahun 2018 telah dilakukan pendampingan untuk menentukan jenis produk salak olahan dan melakukan pelatihan - pelatihan membuat variasi produk salak olaha. Disamping itu telah dibentuk kelompok usaha untuk mengelola usaha tersebut secara sungguh-sungguh. Dari pendampingan th 2018 tersebut, dilakukan identifikasi kebutuhan kelompok setelah belajar membuat produk olahan salak. Dari hasil identifikasi tersebut diperoleh kesimpulan bahwa kelompok membutuhkan peralatan untuk meningkatkan kualitas produk dan penguatan organisasi. Berdasarkan identifikasi masalah dan kebutuhan kelompok maka pada Januari 2019 dilakukan pendampingan sesuai kebutuhan kelompok. Pada awal th 2019 kelompok mengikuti pameran - pameran yang diselenggarakan desa, kecamatan bahkan kabupaten. Hasil pameran tersebut menunjukan bahwa produk cukup diminati oleh masyarakat, dan mendapat masukan dari beberapa toko oleh - oleh serta konsumen bahwa selalu ditanyakan Produk Industri Rumah Tangga (P-IRT). Berdasarkan fakta tersebut maka diusulkan oleh kelompok, untuk program pembelian alat dirubah menjadi program pengurusan ijin P-IRT. Berdasarkan hal tersebut maka dilakukan perubahan program pendampingan. Pendampingan untuk meningkatkan penguatan organisasi berupa peningkatan kapasitas tentang organisasi bisnis, manajemen produksi, manajemen pemasaran, manajemen keuangan, manajemen sumberdaya manusia. Penguatan organisasi ini akan membantu kelompok untuk mengembangkan usaha kelompok. pendampingan untuk pembelian alat yang untuk meningkatkan kualitas maka dirubah menjadi pendampingan pengurusan PIRT. Untuk program peningkatan kualitas produk saat ini menggunakan alat yang ada saat ini disamping itu untuk alat yang belum dimiliki dapat pinjam dari pengusaha lain yang sudah jalan.
\end{abstract}

Kata kunci: Penguatan organisasi, P-IRT, dan kelompok usaha salak

\section{PENDAHULUAN}

Mitra adalah petani salak kelompok salak Aditya Yodha Wadah salak di Dusun Sorowangsan Desa Girikerto Kecamatan Turi Kabupaten Sleman. Masalah yang dihadapi adalah harga salak pada saat panen saat produk melimpah yang kurang menguntungkan dan produk yang mudah busuk. Terbatasnya pengetahuan manajemen usaha dan penjualan atau pemasaran salak yang masih terbatas di lingkungan sekitar, perlu peningkatan kapasitas supaya masyarakat petani salak menjadi lebih sejahtera

Berdasarkan hal tersebut maka telah dilakukan pendampingan untuk melakukan pemberdayaan masyarakat agar dapat mandiri dan menjadi wirausaha yang professional. Pendampingan yang telah dilakukan adalah pengembangan produk pengolahan buah salak agar dapat memiliki nilai tambah. Kesadaran perlunya pengembangan kemandirian dan saat ini telah terbentuk kelompok usaha salak olahan. Disamping itu kelompok membutuhkan pendampingan untuk penguatan organisasi dan peralatan untuk meningkatkan kualitas produk. Kelompok usaha berupaya untuk mengikuti berbagai pameran yang diselenggarakan oleh desa, kecamatan atau kabupaten, untuk mengetahui minat masyarakat terhadap produknya. Selama mengikuti pameran atau menitipkan produknya ke toko- toko atau warung - warung yang ditanyakan oleh konsumen nomor Pangan 
Industri Rumah Tangga (P-IRT), sedangkan kebutuhan alat digunakan alat yang sudah ada sedangkan alat yang belum dimiliki dapat meminjam ke pengusaha lain. Berdasarkan kenyataan tersebut maka dilakukan penyesuaian kebutuhan kelompok. Penyesuaian pendampingan adalah tetap memberikan penguatan organisasi berupa maanjemen organisasi, manajemen produksi, manajemen pemasaran dan manajemen sumber daya kelompok serta mengubah pembelian alat menjadi pengurusan P-IRT. Penguatan organisasi sangat diperlukan karena potensi daerah yang cocok untuk pertanian salak memadai merupakan modal untuk melakukan pemberdayaan masyarakat pengembangan usaha, dengan meningkatkan kapasitas kelompok, sehingga kemampuan metode pemasaran meningkat agar penjualan dapat menjangkau pasar yang lebih luas. Kemampuan organisasi dan manajemen lainya seperti manajemen produksi, keuangan dan sumber daya kelompok meningkat sehingga pengelolaan usaha menjadi lebih memadai. Diharapkan usaha kelompok terus berkembang.

Berdasarkan uraian tersebut di atas maka Permasalahan yang dihadapi oleh kelompok mitra adalah

a. Keterbatasan kemampuan dalam melakukan proses organisasi, manajemen usaha, Keterbatasan kemampuan manajemen pemasaran, teknik penjualan, manajemen produksi, manajemen keuangan dan manajemen sumberdaya kelompok.

b. Keterbatasan alat untuk mendukung kualitas produk, akan tetapi karena kelompok lebih membutuhkan P-IRT maka kebutuhan alat dirubah menjadi proses pengurusan PIRT.

\section{METODE PELAKSANAAN PKM}

Untuk melakukan pendampingan didasarkan pada konsep kapitalisme kreatif. Konsep kapitalisme kreatif adalah menggunakan capital secara kreatif. Yang dimaksud kapitala adalah social capital (jejaring), intellectual capital, technology capital, dan juga financial capital Tujuan Kapitalisme kreatif adalah memberdayakan yang bersifat berkelanjutan untuk menciptakan kesejahteraan dan kemandirian masyarakat. (Swa 24/XXIV/13 - 23 November 2008). Konsep kapitalisme kreatif disebut sinergi 4 kaki seperti pada Gambar 1.

\section{Strategi Sinergi creative : 4 kaki}

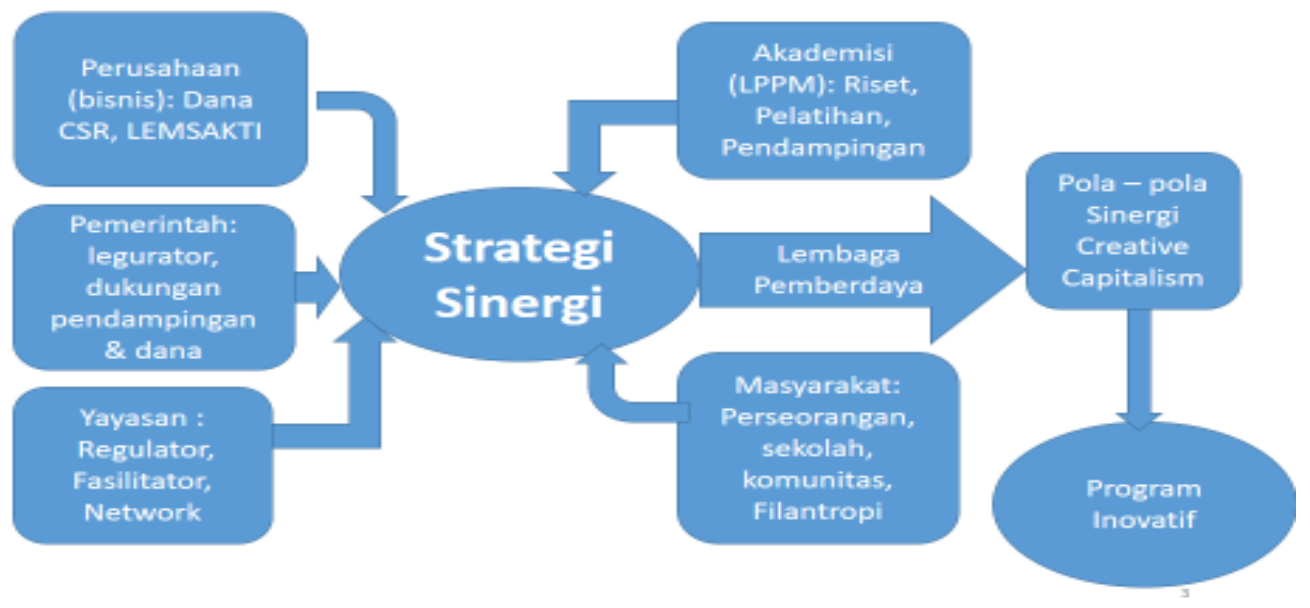

Gambar 1. Strategi sinergi kreatif 4 kaki

Yang dimaksud strategi sinergi 4 kaki merupakan kerjasama antara 4 unsur yang terdiri dari : 
a. kaki 1 adalah perusahaan (bisnis), yang berfungsi mendukung pendanaan, dan sering berbentuk financial capital.

b. kaki yang 2 adalah pemerintah, yang berfungsi pendanaan, regulasi, insentif, fasilitator dan jejaring.

c. kaki yang ke 3 adalah perguruan tinggi atau akademisi yang berfungsi sebagai lembaga pendamping atau advokasi (pendampingan), riset, pelatihan.

d. kaki yang ke 4 adalah perorangan atau filantropiyang berfungs sebagai katalisator, pendanaan, dan filantropi.

Ke empat kaki tersebut bekerjasama atau bersinergi untuk membangun atau memberdayakan untuk kesejahteraan masyarakat.

Berdasarkan konsep tersebut dalam pengambdian masyarakat yang dilakukan ini melibatkan perguruan tinggi Universitas Kristen Duta Wacana sebagai salah satu kaki yang berfungsi sebagai pendamping (advokasi), dan pelatihan untuk meningkatkan kapasitas masyarakat dampingan tersebut. Dalam kegiatannya juga melibatkan Filantropi sebagai perseorangan yang membuat yayasan yang selama ini juga mendampingi komunitas Aditya Yodha dalam pengembangan masyarakat. Selanjutnya perguruan Tinggi dalam hal ini Fakultas Bisnis melalui Lembaga Penelitian dan Pengabdian Masyarakatnya melakukan kegiatan sebagai berikut : (Swa 24/XXIV/13 - 23 November 2008).

Selanjutnya metode program pengabdian yang akan dilakukan PKM adalah dengan Memberikan pendampingan dan pelatihan berdasarkan Permasalahan yang dihadapi oleh kelompok sebagai berikut :

1. Keterbatasan kemampuan dalam melakukan proses organisasi, manajemen usaha, Keterbatasan kemampuan manajemen pemasaran, teknik penjualan, manajemen produksi, manajemen keuangan dan manajemen sumberdaya kelompok.

2. Keterbatasan alat untuk mendukung kualitas produk, akan tetapi karena kelompok lebih membutuhkan P-IRT maka kebutuhan alat dirubah menjadi proses pengurusan PIRT.

Tahapan metode penyelesaian masalah dilakukan, dengan melakukan kegiatan pendampingan terus menerus, pelatihan dan memberikan pendampingan pengurusan P-IRT. Pendampingan terus menerus adalah kehadiran Tim secara rutin ke kelompok tersebut untuk membahas keberhasilan, memotivasi usaha, membangun daya juang kelompok, kesulitan - kesulitan kelompok yang dihadapi. Disela - sela pendampingan tersebut dilakukan pelatihan - pelatihan :

1. Penguatan organisasi.

Penguatan organisasi yang telah dilakukan adalah penguatan organisasi berupa pelatihan - pelatihan sebagai berikut :

a. Pelatihan tentang social entrepreneur sebagai bentuk motivasi untuk kelompok

Dibahas tentang kewirausahaan social, yang merupakan pemberdayaan masyarakat sesuai kondisi potensi daerah, yang tujuannya bukan mencari profit akan tetapi masyarakat menyadari dengan sendirinya potensi daerah dan kesadaran untuk memanfaatkan potensi daerah dan kesadaran untuk mengembangkan potensi daerah tersebut. Kewirausahaan social dapat menjadi jalan untuk mengembangkan usaha bisnis.

b. Pelatihan manajemen produksi 
Manajemen produksi adalah membuat perencanaan produksi dan melaksanakan produksi serta melakukan pengendalian produksi. Produksi dibuat berdasarkan pemasaran yang dilakukannya. Jika pemasarannya meningkat maka produksi juga meningkat. Dalam manajemen produksi harus memperhatikan persediaan bahan mentah maupun barang jadi.

c. Manajemen sumberdaya manusia kelompok

Sebenarnya jumlah anggota kelompok dan pengurusnya jumlahnya 21 orang, akan tetapi dalam pertemuan kelompok memutuskan bahwa ditentukan pengurus, sehingga diperlukan pengaturan, melanisme yang harus dilakukan dalam kelompok. Ditentukan siapa yang menjadi ketua, wakil ketua, bendahara, bagian pemasaran,.

d. Pelatihan manajemen keuangan

Manajemen keuangan merupakan pengelolaan keuanagn kelompok, yang meliputi sumber dan penggunaan dana dan teknis pencatatan keuangan sederhana

e. Pelatihan manajemen pemasaran

Pelatihan dan pendampingan survey pasar, teknik penjualan untuk pengembangan pasar dengan metode konvensional, promosi dan pemasaran yang memanfaatkan IT yaitu penjualan online atau daring.

2. Pendampingan pembelian alat dirubah menjadi pendampingan proses pengurusan PIRT. Dengan pendampingan ini kelompok diminta melakukan beberapa hal sebagai berikut :

a. Membahas arti penting dan nilai tambah P-IRT untuk suatu usaha

b. Mencari informasi persyaratan untuk mendapatkan ijin - PIRT, bersama - sama membahas dan mengidentifikasi kemudahan atau kesulitan dalam memenuhi persyaratan tersebut.

c. Membahas langkah - langkah atau prosedur untuk memperoleh P-IRT

d. Mengidentifikasi rencana yang akan ditentukan sebagai tempat usaha yang merupakan persyaratan penting untuk memenuhi perolehan ijin P-IRT.

\section{HASIL DAN PEMBAHASAN}

Dari kegiatan pendampingan yang dilakukan mulai dari pelatihan - pelatihan dapat diperoleh hasil sebagai berikut :

a. Kelompok menjadi merasa lebih mengerti tentang manajemen, akan tetapi masih mengalami kesulitan - kesulitan terutama untuk merencanakan produksi, mengevaluasi produksi.

b. Untuk pemasaran yang masih mengalami kesulitan adalah survey pasar, promosi.

c. Untuk manajemen sumber daya manusia kelompok terus belajar untuk bekerjasama dan saling menghargai.

d. Untuk pemasaran menggunakan system dharing telah dapat dilakukan walaupun masih menggunakan Whatsup, akan tetapi dapat dilakukan, dan sedang akan mengikuti pelatihan system penjualan online (dharing) 
e. Untuk hal - hal yang masih dirasakan sulit dapat dimengerti karena untuk melakukan system manajerial seperti manajemen organisasi, pemasaran, keuangan dan sumberdaya, sebaiknya dilakukan secara rutin dan terus menerus. Jika latihan hanya dilakukan satu kali atau dua kali tentu berlum cukup. Oleh karena itu pendampingan terus dilanjutkan.

f. Untuk proses P-IRT, agar dapat dilakukan dengan baik oleh kelompok maka dibrikan pelatihan atau wawasan tentang pengertian dan manfaat dari P-IRT. Sertifikat Produksi Pangan - Industri Rumah Tangga (SPP-IRT) adalah jaminan tertulis yang diberikan oleh Bupati/Walikota - melalui Dinas Kesehatan - terhadap pangan hasil produksi Industri Rumah Tangga yang telah memenuhi persyaratan dan standar keamanan tertentu, dalam rangka produksi dan peredaran produk pangan (Siti Umaiyah, http://jogya.tribunnews.com).

P-IRT sebagai daftar dari Dinas Kesehatan yang merupakan salah satu hal yang dipertimbangkan konsumen untuk membeli suatu produk, artinya bahwa nilai jual suatu produk antara lain dipengaruhi oleh P-IRT. Hal tersebut terjadi karena konsumen akan merasa aman dalam melakukan pembelian makanan dan minuman jika produk tersebut telah memiliki P-IRT. Kelompok dalam melakukan penjualan juga mengalami kebutuhan P-IRT, karena setiap melakukan penjualan (menitipkan ke Toko atau menerima pesanan) konsumen selalu menanyakan P-IRT. Berdasarkan kondisi twersebut maka dana yang sedianya untk membeli alat dilihkan untuk mengurus proses P-IRT).

P-IRT sangat penting bagi usaha makanan dan minuman, dengan memiliki P-IRT produk akan memiliki keunggulan sebagai berikut :

1) Produk layak jual., konsumen merasa aman untuk mengkonsumsi makanan tersebut.

2) Produk dapat dipasarkan secara luas, pengusaha dapat mengembangkan pasar lebih luas, ke seluruh Indonesia

3) Keamanan dan mutu terjamin, dengan memiliki P-IRT maka produk tentu telah diperiksa oleh Dinas Kesehatan, hal tersebut mengindikasikan bahwa produk aman dikonsumsi.

4) Dll.

g. Kelompok saat ini sedang mempelajari serta berupaya untuk memenuhi persyaratan pengurusan P-IRT.

Tabel Proses P-IRT

\begin{tabular}{|l|l|l|l|}
\hline No & Persyaratan & Hasil & Keterangan \\
\hline 1 & Pas foto 3 x 4 sebanyak dua lembar & Terpenuhi & \\
\hline 2 & Fc KTP & Terpenuhi & \\
\hline 3 & Surat keterangan domisili usaha & Tersedia & $\begin{array}{l}\text { Tempat usaha masih } \\
\text { perlu dibenahi }\end{array}$ \\
\hline 4 & Surat keterangan puskesmas atau dokter & Proses & \\
\hline 5 & Denah lokasi dan denah bangunan & Proses & \\
\hline 6 & $\begin{array}{l}\text { Rincian modal usaha dari kelurahan } \\
\text { setempat }\end{array}$ & Proses & \\
\hline 7 & $\begin{array}{l}\text { Surat keterangan usaha dari kelurahan } \\
\text { setempat }\end{array}$ & Proses & $\begin{array}{l}\text { Sudah } \\
\text { dibuat }\end{array}$ \\
\hline 8 & $\begin{array}{l}\text { Contoh draft label/kemasan } \\
\text { kesepakatan bulat }\end{array}$ \\
\hline 9 & Sampel produk pangan & Terseda & \\
\hline
\end{tabular}




\begin{tabular}{|l|l|l|l|}
\hline 10 & $\begin{array}{l}\text { Surat pernyataan kepemilikan jika } \\
\text { berbentuk CV/PT }\end{array}$ & Belum & $\begin{array}{l}\text { Masih harus } \\
\text { memastikan dan } \\
\text { menyepakati bentuk } \\
\text { usaha }\end{array}$ \\
\hline
\end{tabular}

\section{KESIMPULAN}

Berdasarkan kegiatan dan hasil pembahasan maka dapat disimpulkan bahwa :

1. Pelatihan penguatan organisasi telah dilakukan dan berjalan dengan lancar, seluruh pengurus kelompok merasa sangat bersemangat untuk mengembangkan usaha.

2. Dari materi pelatihan yang diberikan, masih ada beberapa kesulitan mengerti penjelasan yang dierima, oleh karena itu pendampingan dan pelatihan masih tetap dilanjutkan untuk program tahun 2020.

3. Pengurusan P-IRT telah dapat dilakukan akan tetapi masih diperlukan tindak lanjut, karena untuk memenuhi persyaratan tempat mebutuhkan biaya, agar tempat layak untuk menjadi tempat usaha.

4. Harapan dari kelompok, dengan berhasilnya pengurusan P-IRT pemasaran dapat berjalan dengan lancar dan berkembang.

\section{REFERENSI}

Agar Kewirausahaan Social Kokoh Berkembang, 2014, Swa No 02/XXX/23 Januari - 5 Februari 2014. penerbit : PT Swasemabad Media Bisnis Jakarta

Darmawan, Januar, 2012, Profit and Beyond : Proses Mencetak Para Wirausaha,. PT Gramedia Pustaka Utama, Kompas Garmedia Building, Blok I Lt 4 - 5 Jl. Palmerah Barat Jakarta.

Hendriani, Lis dkk, Indonesia's Best Practices of Corporate Social Initiative, Agustus 2018, penerbit : PT Swasemabad Media Bisnis Jakarta

Kapitalisme Kreatif, 2008, Swa no 24/XXIV/13 - 23 November 2008, Penerbit : PT

Swasemabad Media Bisnis Jakarta

Menanti Jutaan Wirausaha dari Social Entrepreneursip, 2010, Swa No 03/XXVI/4 - 17 Februari 2010. Penerbit : PT Swasemabad Media Bisnis Jakarta , Memberi \& Memberdayakan, cara baru membesarkan Bisnis, 2014, Swa No

02/XXX/23 Januari - 5 Februari 2014. Penerbit : PT Swasemabad Media Bisnis. Jakarta , Menebar Virus Social Entrepreneurship, 2014. Swa No 02/XXX/23 Januari - 5

Februari 2014. Penerbit : PT Swasemabad Media Bisnis. Jakarta

Murdjito, Gatot, 2012. Metoda Pengabdian pada Masyarakat, bahan pelatihan metodologi pengabdian kepada Masyarakat Universitas Gadjah Mada, Yogyakarta , Tak Cukup Bermodal Niat Baik, 2015. Swa 21/XXXI/31 September - 13

Oktober 2015. Penerbit : PT Swasemabad Media Bisnis. Jakarta

Rangkuti, Fredy 2000. Business Plan: Teknik membuat perencanaan bisnis \& Analisis kasus.

Oktober 2000. Jakarta 